\title{
Influence of antioxidative and antibacterial activity of sage aqueous extract and chitosan formulation on chicken burger quality
}

\author{
ANETA CEGIEŁKA ${ }^{1}$, ELŻBIETA HAĆ-SZYMAŃCZUK², \\ KATARZYNA FRĄCZKIEWICZ ${ }^{2}$, MARTA CHMIEL ${ }^{1}$
}

\begin{abstract}
1Department of Food Technology and Food Evaluation, ${ }^{2}$ Department of Biotechnology and Food Microbiology, Institute of Food Sciences, Warsaw University of Life Sciences - SGGW, Nowoursynowska 166, 02-787 Warsaw, Poland
\end{abstract}

\section{Cegiełka A., Hać-Szymańczuk E., Frączkiewicz K., Chmiel M. \\ Influence of antioxidative and antibacterial activity of sage aqueous extract and chitosan formulation on chicken burger quality}

Summary

The aim of the present study was to assess the antioxidative and antibacterial activity of sage (Salvia officinalis L.) aqueous extract and chitosan formulation in chicken burgers during storage. Four burger treatments were prepared: $\mathrm{C}$ - without sage extract and chitosan formulation, $\mathrm{S}$ - with $2.0 \%$ of sage extract, $\mathrm{CH}$ - with $1.0 \%$ of chitosan formulation, and $\mathrm{SCH}$ - with $2.0 \%$ of sage extract and $1.0 \%$ of chitosan formulation. On the production day, the chemical composition of poultry burgers was analyzed. After 0,7 and 14 days of storage in burgers, the advancement of the lipid oxidation process was assessed and microbiological analyses were performed. Microbiological analyses included the determination of the total count of mesophilic aerobic microorganisms and that of psychrotrophic bacteria, count of coliform bacteria, count of Pseudomonas, and count of lactic acid bacteria. One of the tested groups of bacteria was Brochothrix thermosphacta, which can cause spoilage of packaged meat products stored under refrigeration temperature. It has been found that aqueous sage extract had significantly $(p<0.05)$ the best antioxidative effect compared to chitosan and the combination of sage extract and chitosan formulation in chicken burgers during the entire storage period. Both aqueous sage extract and chitosan formulation exhibited antibacterial activity in chicken burgers, although the efficiency of growth inhibition differed between the tested bacteria groups. After 14 days of storage of burgers, the significantly $(p<0.05)$ lowest number of mesophilic aerobic microorganisms, Pseudomonas spp., and $B$. thermosphacta were found in burgers with the combination of sage extract and chitosan formulation.

Keywords: chicken burgers, chitosan preparation, sage aqueous extract, microbial quality

Convenience foods are generally defined as a set of food products obtained by raw material processing which reduces the intensity of labor required to prepare the meal. The safety and stability of such foods are of great importance to the consumers. The poultry industry offers a wide range of convenience food products that are ready to eat after reheating. Many of these products, such as nuggets, are traditionally prepared from poultry meat. The prototype for other convenience food products made from poultry meat such as burgers - are those originally made from mammalian meat. Convenience foods made from poultry meat sold in cooled form are characterized by a short shelf-life, typically below 10 days. Microbial stability of these products during distribution and storage can be achieved via heat treatment and appropriate packaging, or by the use of preservatives (22). A safe alternative to synthetic additives used in the production of food of red meat and poultry meat products is the natural substances isolated from plants. These include extracts and essential oils obtained from spice plants, such as sage, rosemary, and oregano $(10,11,13,16)$. Furthermore, to ensure the shelf-life of poultry meat-based products, it is important to control the course of the lipid oxidation processes, as these foods are particularly susceptible to oxidative deterioration $(1,34)$.

Sage (Salvia officinalis L.) is a plant originally from the Mediterranean area, classified under the Lamiaceae family. The cultivars of Salvia officinalis, Salvia scarea, and Salvia pretensis are commonly grown 
worldwide. Data from studies show that sage exhibits stronger biological effects against Gram-positive bacteria, and weaker effects against Gram-negative bacteria and pathogenic fungi $(10,11)$. It should be noted that the efficacy of antibacterial plant formulations depends on the form in which they are added to foods; for example, as essential oil, aqueous or alcohol extract, or dried plant. These formulations differ in the type and content of chemical components $(11,13)$.

Chitosan is another substance of natural origin having a wide range of applications in the food industry. This biopolymer is obtained through the deacetylation of chitin, which is found in various materials, e.g. crustacean shells (32). Research shows that the antioxidative and antimicrobial properties of chitosan can allow prolonging the shelf-life and safety of meat and its products (4). Chitosan formulation is directly added to meat and meat products $(7,8)$, or alternatively, chitosan coatings are applied on the product surface (35). The antibacterial and antioxidative effects of chitosan coatings intended for meat products can be enhanced via the addition of plant formulations (18).

The wide circles of convenience meat consumers and successful attempts made at improving the quality of such products using sage extracts (17) on one hand and chitosan formulation $(7,33,35)$ on the other validate the need to continue studies on enhancing the safety of such products with the use of natural ingredients. Thus far, no works are found in the literature concerning the impact of aqueous sage extract and chitosan formulation on the quality of chicken meat products of convenience food type. Therefore, the present study aimed to assess the antioxidative and antibacterial activities of sage (S. officinalis L.) aqueous extract and chitosan formulation in chicken meat burgers during storage.

\section{Material and methods}

Study material. The raw materials for the production of burgers were cooled chicken thigh meat and cooled pork jowl, which were purchased in one of the supermarkets in Warsaw (Poland). For each given experimental series, approximately $5.5 \mathrm{~kg}$ of chicken thigh meat and $1.5 \mathrm{~kg}$ of pork jowl were used. The raw materials were supplied by the same meat processing plant located near Warsaw. They were transported to the laboratory (Institute of Food Sciences, Warsaw University of Life Sciences - SGGW, Warsaw, Poland) under refrigeration storage conditions (thermal insulation box with cooling inserts). Immediately after the raw materials were brought, the production of burgers started. The chicken meat and pork jowl were ground separately in a meat grinder (Mesko WN60, Mesko AGD Sp. z o.o., Skarżysko-Kamienna, Poland), equipped with a cutting set with a sieve mesh of $4.5 \mathrm{~mm}$. The ground chicken meat and pork jowl were separately mixed by hand and divided into four portions.

Three experimental series of burgers were performed. In each of the experimental series, four burger treatments with constant recipe composition were prepared: chicken thigh meat $85 \%$, skinned jowl $15 \%$, and other minor ingredients relative to the weight of the mentioned meat-fat components (table salt $1.8 \%$, black pepper ground $0.15 \%$, and herbal pepper ground $0.15 \%$ ). The burgers differed in the amount of aqueous sage extract and chitosan formulation added: C-product without the addition of sage extract and chitosan formulation (control), S-product with the addition of $2.0 \%$ $(\mathrm{w} / \mathrm{w})$ aqueous sage extract, $\mathrm{CH}$-product with the addition of $1.0 \%(\mathrm{w} / \mathrm{w})$ chitosan formulation, and $\mathrm{SCH}$-product with the addition of $2.0 \%(\mathrm{w} / \mathrm{w})$ aqueous sage extract and $1.0 \%$ $(\mathrm{w} / \mathrm{w})$ chitosan formulation. For the production of burgers, a commercial preparation of chitosan (no. CAS 9012-76-4, Sigma-Aldrich, St. Louis, MO, USA) and a water extract of sage prepared by the authors (Institute of Food Sciences, Warsaw University of Life Sciences-SGGW) were used. The amount of the addition of chitosan preparation and aqueous sage extract was assumed on the basis of previous studies $(7,10,33)$.

The meat batter for burgers was prepared using a laboratory mixer (Kenwood Major KM800, Kenwood Ltd., Havant, UK), starting from mixing the chicken meat with table salt and spices. After 5 min, aqueous sage extract was added (treatments: $\mathrm{S}$ and $\mathrm{SCH}$ ), followed by chitosan formulation (treatments: $\mathrm{CH}$ and $\mathrm{SCH}$ ) and jowl (all treatments). The total time taken for mixing was $15 \mathrm{~min}$. Burgers were formed using a manual molding machine. The burgers were heat-treated in a convection steam oven (Rational Self Cooking Center ${ }^{\circledR}$, Rational, Rolling Meadows, IL, USA) at $180^{\circ} \mathrm{C}$ (air relative humidity $10 \%$, hot air circulation on) until a temperature of $72^{\circ} \mathrm{C}$ was achieved in the product center. Next, the burgers were cooled down in an ambient temperature (about $18^{\circ} \mathrm{C}$ ) for $30 \mathrm{~min}$. After vacuum packing into multilayer foil bags using a packing machine (Multivac C200, Multivac Sepp Haggenmüller GmbH\&Co. KG, Wolfertschwenden, Germany), the burgers were stored in the cold room $\left(+4^{\circ} \mathrm{C} \pm 1^{\circ} \mathrm{C}\right)$ for 14 days.

Preparation of aqueous sage extract. Aqueous extract of sage (S. officinalis L., leaf; Nanga, Złotów, Poland) was obtained by continuous extraction using an extraction system (B-811 Universal Extraction System, Büchi Labortechnik AG, Flawil, Switzerland). For this purpose, $40 \mathrm{~g}$ of dried sage was distributed into eight extraction thimbles ( $5 \mathrm{~g}$ per each thimble). The raw material placed in the thimbles was extracted with $150 \mathrm{~mL}$ of solvent (distilled water) for $15 \mathrm{~min}$, maintaining the boiling temperature. The portions of the water extract obtained were combined, which resulted in $550 \mathrm{~mL}$ of raw extract. Next, the raw extract was filtered through a filter paper. Subsequently, it was concentrated in a rotary evaporator (Rotovaporator R-300, Büchi Labortechnik AG) until $40 \mathrm{~g}$ was obtained, which was the mass corresponding to the weight of the dried plant used to obtain the extract.

Methods. The determination of the content of chemical components in the products was carried out on the day of production (day 0). The value of thiobarbituric acid reactive substances (TBARS) and microbiological analyses were performed on day 0 and on days 7 and 14 of storage.

Determination of chemical composition. The content of water, protein, fat, salt, and total carbohydrates in the burgers was determined using a near-infrared spectrometer 
FoodScan ${ }^{\mathrm{TM}} 2$ (Foss Analytical A/S, Hillerød, Denmark), which works in a spectrum range from 850 to $1500 \mathrm{~nm}$, utilizing an artificial neural network calibration model (25). The measurement samples were prepared by grinding 300 $\mathrm{g}$ of product twice in a laboratory mincer (Mesko WN60, Mesko AGD Sp. z o.o.) through a sieve with a mesh size of $2 \mathrm{~mm}$ followed by thorough mixing. The minced product was filled in a cuvette and placed on the measurement station. For each product sample in each experimental series, the reading was taken twice and the mean value was assumed as the result.

Determination of thiobarbituric acid reactive substances. The value of TBARS indicator was determined using the extraction method described by Pikul et al. (24). The product samples minced in the laboratory mincer (sieve mesh size of $2 \mathrm{~mm}$ ) and weighing $10 \mathrm{~g}$ were homogenized with $34.25 \mathrm{~mL}$ of cold (temperature $+4^{\circ} \mathrm{C}$ ) $4 \%$ perchloric acid and $0.75 \mathrm{~mL}$ of $0.01 \%$ alcohol solution of butylated hydroxytoluene in a homogenizer (SilentCrusher M, Heidolph Instruments GmbH\&Co. KG, Schwabach, Germany) for $1 \mathrm{~min}$. The homogenate was filtered through a Whatman no. 1 filter paper to a measuring flask of $50 \mathrm{~mL}$ volume. The obtained filtrate was made up to $50 \mathrm{~mL}$ by washing the precipitate with cold (temperature $+4^{\circ} \mathrm{C}$ ) $4 \%$ perchloric acid. After mixing, $5 \mathrm{~mL}$ of filtrate was collected and transferred to a test tube, to which $5 \mathrm{~mL}$ of $0.02 \mathrm{M}$ aqueous solution of 2-thiobarbituric acid (TBA) was subsequently added. The samples were closed with corks and heated in a boiling water bath for $60 \mathrm{~min}$. Subsequently, tubes containing the solution were cooled for $10 \mathrm{~min}$ in cold running water, and absorbance was read at $532 \mathrm{~nm}$ wavelength using a spectrophotometer (CamSpec M501, CamSpec Ltd., Leeds, UK) against the test solution containing $5 \mathrm{~mL}$ of $4 \%$ perchloric acid and $5 \mathrm{~mL}$ of TBA. The TBARS indicator expressed in $\mathrm{mg}$ of malondialdehyde (MDA) per $\mathrm{kg}$ of product (mg MDA $/ \mathrm{kg}$ ) was calculated using the formula: TBARS $=\mathrm{A} \times \mathrm{K}$, where $\mathrm{A}$ is the absorbance value of the test sample and $\mathrm{K}$ is the calculation coefficient $(\mathrm{K}=5.5)$. In each experimental series, the TBARS determination was performed in duplicate for each product treatment.

Microbiological analyses. Burger samples for microbiological tests were prepared in accordance with PN-EN ISO 6887-2: 2005 (27). For each burger variant $20 \mathrm{~g}$ of product was taken for microbiological analyses. The foil packaging containing burgers was opened using a sterile scalpel. $20 \mathrm{~g}$ of the sample was taken using a sterile spoon and transferred to $180 \mathrm{~mL}$ of $0.1 \%$ sterile peptone water (bioMérieux, Paris, France). Each sample was homogenized in a Stomacher blender (Lab Blender 400 Circulator, Seward Laboratory, London, UK) for 1 min at high speed and at room temperature $\left(18^{\circ} \mathrm{C}\right)$. Furthermore, a series of 10 -fold dilutions in sterile peptone water was prepared.
Microbiological analyses included the determination of different groups of bacteria. The analysis of the total count of mesophilic aerobic microorganisms was performed according to PN-EN ISO 4833-1:2013-12 (26) and that of psychrotrophic bacteria according to PN-ISO 17410:2004 (31) on a Plate Count Agar medium (BTL Sp. z o. o., Łódź, Poland). The count of coliform bacteria was determined according to PN-ISO 4832:2007 (28) on an Agar Endo medium (BTL Sp. z o. o.). The analysis of Pseudomonas was performed according to PN-EN ISO 13720:2010 (29) on a King B medium (BTL Sp. z o. o.). The count of lactic acid bacteria was determined according to PN-ISO 15214:2002 (30) on de Man, Rogosa, and Sharpe medium (BTL Sp. $\mathrm{Z}$ o.o.). The count of Brochothrix thermosphacta (room temperature, $48 \mathrm{~h}$ ) was determined according to Nowak et al. (19) on Streptomycin Sulphate-Thallous AcetateActidione Agar medium (Oxoid Ltd., Basingstoke, UK). All the bacterial counts were expressed as colony forming units (CFU) per g of product (CFU/g). In each experimental series, microbiological analyses were performed in duplicate for each product treatment.

Statistical analysis. Statistical analysis of the results was performed using Statgraphics Centurion $18^{\circledR}$ (Statgraphics Technologies Inc., The Plains, VA, USA). One-way ANOVA statistical test was used to determine the differences between the mean values. Tukey test was used to determine the significance of differences. All calculations were performed at the significance level $\alpha=0.05$. Before performing the oneway ANOVA tests, the normality of the data distribution was checked using the Shapiro-Wilk test. The homogeneity of variance was checked with the Leleven test.

\section{Results and discussion}

Chemical indicators of chicken burger quality. In the present study, chicken meat burgers contained about $65 \%$ water, $17.4-19.3 \%$ protein, $12.6-13.2 \%$ fat, and slightly over $2 \%$ sodium chloride (Tab. 1 ). The minor, yet significant $(p<0.05)$ differences in the content of fat, protein, and water content observed between the products could be linked with the minor natural variability of raw materials: chicken meat, and mainly pork jowl, used in their production and water loss during the heat treatment (roasting). The results obtained by Ozaki et al. (20) suggested that the addition of chitosan formulation $(0.25 \%$ and $0.5 \%)$ to fermented cooked

Tab. 1. Content of selected chemical components in chicken burgers containing aqueous sage extract and chitosan formulation $(\bar{x} \pm S D ; n=6)$

\begin{tabular}{|l|c|c|c|c|c|}
\hline Treatment & Water (\%) & Protein (\%) & Fat (\%) & $\begin{array}{c}\text { Sodium chloride } \\
(\%)\end{array}$ & $\begin{array}{c}\text { Total } \\
\text { carbohydrates (\%) }\end{array}$ \\
\hline C & $64.9 \pm 0.49^{\mathrm{a}}$ & $19.3 \pm 0.44^{\mathrm{c}}$ & $12.9 \pm 0.22^{\mathrm{b}}$ & $2.1 \pm 0.02^{\mathrm{a}}$ & $0.0 \pm 0.0^{\mathrm{a}}$ \\
S & $65.7 \pm 0.44^{\mathrm{b}}$ & $18.3 \pm 0.11^{\mathrm{b}}$ & $13.2 \pm 0.33^{\mathrm{c}}$ & $2.1 \pm 0.05^{\mathrm{a}}$ & $0.0 \pm 0.0^{\mathrm{a}}$ \\
CH & $65.7 \pm 0.09^{\mathrm{b}}$ & $17.6 \pm 0.34^{\mathrm{a}}$ & $12.6 \pm 0.03^{\mathrm{a}}$ & $2.1 \pm 0.03^{\mathrm{a}}$ & $0.9 \pm 0.24^{\mathrm{b}}$ \\
SCH & $65.7 \pm 0.50^{\mathrm{b}}$ & $17.4 \pm 0.11^{\mathrm{a}}$ & $13.0 \pm 0.33^{\mathrm{bc}}$ & $2.1 \pm 0.07^{\mathrm{a}}$ & $0.7 \pm 0.33^{\mathrm{b}}$ \\
\hline
\end{tabular}

Explanations: $\mathrm{C}$ - product without the addition of sage extract and chitosan formulation (control); $\mathrm{S}$ - product with the addition of $2.0 \%(w / w)$ aqueous sage extract; $\mathrm{CH}$ - product with the addition of $1.0 \%(w / w)$ chitosan formulation; $\mathrm{SCH}$ - product with the addition of $2.0 \%(w / w)$ aqueous sage extract and $1.0 \%(w / w)$ chitosan formulation; $\mathrm{a}, \mathrm{b}, \mathrm{c}-$ mean values within the same column with different superscript letters differ significantly at $\mathrm{p}<0.05$ among treatments 
sausage did not significantly change its basic chemical composition immediately after preparation. However, after 10 days of storage, significant $(\mathrm{p}<0.05)$ differences were observed in the content of water and fat between the control product and the products with chitosan (20).

In our study, the results showed that the addition of chitosan formulation (treatments: $\mathrm{CH}$ and $\mathrm{SCH}$ ) significantly differentiated $(p<0.05)$ the content of total carbohydrates in chicken meat burgers from that of products not containing chitosan (treatments: $\mathrm{C}$ and S). However, the content of carbohydrates in $\mathrm{CH}$ and $\mathrm{SCH}$ burgers was lower than $1 \%$. Chitosan is a compound classified among polysaccharides, and thus, its presence in the recipe composition determined their content in burgers.

In the present study, the mean value of

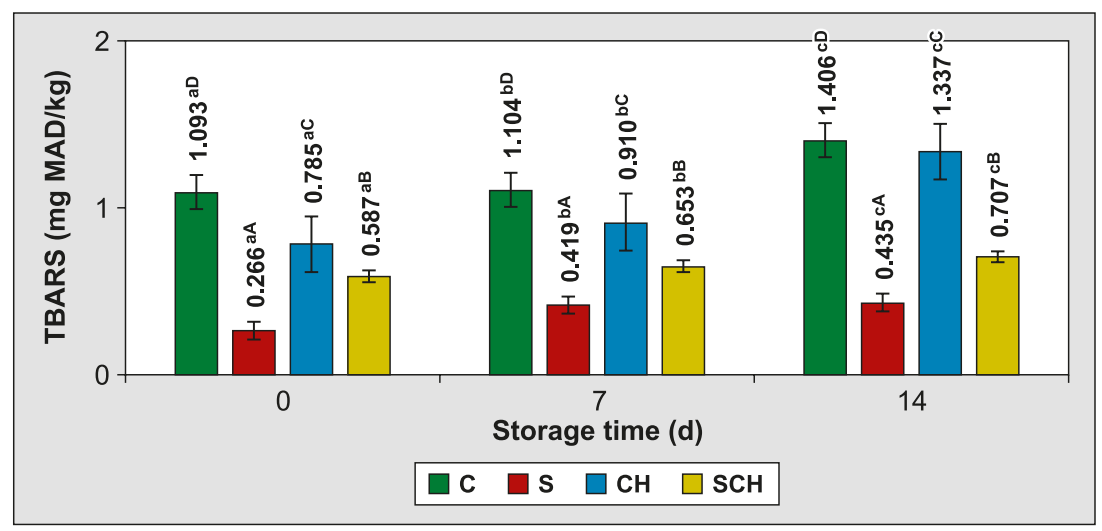

Fig. 1. Effect of the addition of aqueous sage extract and chitosan formulation on the TBARS index in chicken burgers during storage $(\bar{x} \pm S D ; n=6)$ Explanations: $\mathrm{C}-$ product without the addition of sage extract and chitosan formulation (control); $\mathrm{S}-$ product with the addition of $2.0 \%(w / w)$ aqueous sage extract; $\mathrm{CH}$ - product with the addition of $1.0 \%(w / w)$ chitosan formulation; $\mathrm{SCH}-$ product with the addition of $2.0 \%(w / w)$ aqueous sage extract and $1.0 \%$ $(w / w)$ chitosan formulation; ${ }^{\mathrm{a}, \mathrm{b}, \mathrm{c}}$ - mean values with different superscript letters differ significantly at $\mathrm{p}<0.05$ among treatments for a given time; A, B, C, D - mean values with different superscript letters differ significantly at $\mathrm{p}<0.05$ among storage time for a given treatment

TBARS in burgers varied significantly $(p<0.05)$ depending on the modifications in recipe composition as well as storage time (Fig. 1). Directly after the production (day 0 ), the level of lipid oxidation was the lowest $(\mathrm{p}<0.05)$ in the $\mathrm{S}$ product, which was indicated by the lowest TBARS value $(0.266 \mathrm{mg} \mathrm{MDA} /$ $\mathrm{kg}$ ), whereas in the $\mathrm{C}$ product it was significantly the highest $(\mathrm{p}<0.05 ; 1.093 \mathrm{mg} \mathrm{MDA} / \mathrm{kg})$. The addition of chitosan ( $\mathrm{CH}$ treatment) resulted in a significant $(p<0.05)$ retardation of lipid oxidation in contrast to $C$ product. Similarly, the addition of both natural components to burgers (SCH treatment) significantly impeded $(\mathrm{p}<0.05)$ the oxidation processes in comparison to the product $\mathrm{CH}$, but the inhibition was not as efficient as in the case of $\mathrm{S}$ product. The differences in the MDA content in the chicken meat burgers remained until 7 days of storage. On day 14, the value of TBARS in C and $\mathrm{CH}$ products did not differ significantly $(\mathrm{p}>0.05)$. Prolongation of the storage time to 7 days resulted in significant $(p<0.05)$ intensification of the lipid peroxidation process only in S product, whereas after 14 days the TBARS value of this product did not increase significantly $(\mathrm{p}>0.05)$. For $\mathrm{C}$ and $\mathrm{CH}$ burgers, significant $(\mathrm{p}<0.05)$ intensification of oxidation occurred between 7 and 14 days of storage. For SCH product, the TBARS value did not increase significantly $(p>0.05)$ during 14 days of storage. However, it should be emphasized that on day 14, the MDA content in S product was still the lowest $(p<0.05)$ in comparison with the remaining products and over threefold lower than in the $\mathrm{C}$ product. This indicates that aqueous sage extract exhibited the greatest antioxidative activity in burgers throughout the storage time.

The TBARS values of chicken meat burgers determined in this study were relatively low. Sohaib et al. (34) showed that at the onset of refrigeration storage the TBARS value of chicken meat patties was $1.93 \mathrm{mg}$ $\mathrm{MDA} / \mathrm{kg}$, whereas after 7 days it increased to $3.47 \mathrm{mg}$ MDA $/ \mathrm{kg}$. According to Pietrzak et al. (23), the TBARS value of chicken meat burgers which were vacuumpacked and stored at a temperature of $4-6^{\circ} \mathrm{C}$ for $24 \mathrm{~h}$ was $2.4 \mathrm{mg} \mathrm{MDA} / \mathrm{kg}$, and after 3 weeks it increased to $2.7 \mathrm{mg} \mathrm{MDA} / \mathrm{kg}$.

Research outcomes show that aqueous sage extract can maintain the oxidative stability of mechanically separated meat (MSM) from chickens which is vacuum packed and stored under refrigeration conditions for up to 14 days (13) and frozen for up to 9 months (5). Based on the TBARS value, it was determined that the effect of aqueous extract of sage in restricting the oxidative lipid changes in MSM from chickens was comparable with other formulations obtained from the plant (i.e. essential oil and ethanol extracts $[70 \%$ and $40 \%$, respectively]). According to Gantner et al. (6), the addition of aqueous sage extract at the amounts of $0.02 \%$ and $0.05 \%$ in turkey meat balls significantly retarded lipid peroxidation between 3 and 6 days of storage in comparison with the control product.

The effect of chitosan formulation in restricting the unfavorable oxidative changes in lipids was found in pork sausage with a reduced content of sodium nitrite (III) (3). However, the results obtained by Ozaki et al. (20) showed that chitosan exhibited a weak antioxidative activity. Therefore, the authors recommend that it can be applied with other natural antioxidants.

Microbiological indicators of chicken burger quality. Independent of the addition of aqueous sage extract and chitosan formulation, the presence of mesophilic aerobic microorganisms was observed in the samples of each of chicken burger treatment (Tab. 2). Throughout the storage time, the greatest level of 
Tab. 2. Microbiological quality of chicken burgers with the addition of aqueous sage extract and chitosan formulation during storage $(\bar{x} \pm S D ; n=6)$

\begin{tabular}{|c|c|c|c|c|}
\hline \multirow{2}{*}{$\begin{array}{l}\text { Time } \\
\text { (d) }\end{array}$} & \multicolumn{4}{|c|}{ Treatment } \\
\hline & C & S & $\mathrm{CH}$ & SCH \\
\hline \multicolumn{5}{|c|}{ Mesophilic aerobic microorganisms count (CFU/g) } \\
\hline 0 & $4.0 \times 10^{1} \pm 1.0 \times 10^{1} \mathrm{bA}$ & $1.3 \times 10^{1} \pm 6.0 \times 10^{0} \mathrm{aA}$ & $2.3 \times 10^{1} \pm 1.5 \times 10^{1} \mathrm{abA}$ & $1.7 \times 10^{1} \pm 5.0 \times 10^{0} \mathrm{aA}$ \\
\hline 7 & $6.6 \times 10^{2} \pm 2.2 \times 10^{2} \mathrm{bA}$ & $2.1 \times 10^{2} \pm 8.0 \times 10^{0} \mathrm{aA}$ & $2.7 \times 10^{2} \pm 6.0 \times 10^{0} \mathrm{aA}$ & $3.0 \times 10^{1} \pm 1.0 \times 10^{1} \mathrm{aA}$ \\
\hline 14 & $9.6 \times 10^{4} \pm 1.7 \times 10^{2} \mathrm{~dB}$ & $2.3 \times 10^{4} \pm 2.6 \times 10^{3} \mathrm{cB}$ & $1.7 \times 10^{4} \pm 2.4 \times 10^{3} \mathrm{bB}$ & $5.8 \times 10^{3} \pm 1.8 \times 10^{3} \mathrm{aB}$ \\
\hline \multicolumn{5}{|c|}{ Psychrotrophic bacteria count (CFU/g) } \\
\hline 0 & $5.6 \times 10^{2} \pm 1.5 \times 10^{2} \mathrm{cA}$ & $2.6 \times 10^{2} \pm 5.7 \times 10^{0} \mathrm{aA}$ & $4.3 \times 10^{2} \pm 1.1 \times 10^{2} \mathrm{bA}$ & $2.6 \times 10^{2} \pm 5.7 \times 10^{0} \mathrm{aA}$ \\
\hline 7 & $6.1 \times 10^{2} \pm 9.0 \times 10^{0} \mathrm{bA}$ & $6.1 \times 10^{2} \pm 9.0 \times 10^{0} \mathrm{aA}$ & $3.8 \times 10^{2} \pm 4.0 \times 10^{0 \mathrm{aA}}$ & $3.0 \times 10^{2} \pm 1.7 \times 10^{2} \mathrm{aA}$ \\
\hline 14 & $5.1 \times 10^{4} \pm 2.1 \times 10^{3} \mathrm{cB}$ & $1.6 \times 10^{4} \pm 4.5 \times 10^{2} \mathrm{abB}$ & $2.0 \times 10^{4} \pm 1.4 \times 10^{3}$ ьв & $5.2 \times 10^{3} \pm 1.3 \times 10^{1} \mathrm{aB}$ \\
\hline \multicolumn{5}{|c|}{ Coliform bacteria count (CFU/g) } \\
\hline 0 & nd in $0.1 \mathrm{~g}$ & nd in $0.1 \mathrm{~g}$ & nd in $0.1 \mathrm{~g}$ & nd in $0.1 \mathrm{~g}$ \\
\hline 7 & nd in $0.1 \mathrm{~g}$ & nd in $0.1 \mathrm{~g}$ & nd in $0.1 \mathrm{~g}$ & nd in $0.1 \mathrm{~g}$ \\
\hline 14 & nd in $0.1 \mathrm{~g}$ & nd in $0.1 \mathrm{~g}$ & nd in $0.1 \mathrm{~g}$ & nd in $0.1 \mathrm{~g}$ \\
\hline \multicolumn{5}{|c|}{ Pseudomonas count (CFU/g) } \\
\hline 0 & $3.4 \times 10^{3} \pm 1.4 \times 10^{2}$ bAB & $2.3 \times 10^{3} \pm 3.5 \times 10^{2} \mathrm{aB}$ & $3.1 \times 10^{3} \pm 4.2 \times 10^{2} \mathrm{aA}$ & $3.1 \times 10^{3} \pm 3.8 \times 10^{2} \mathrm{bC}$ \\
\hline 7 & $1.4 \times 10^{3} \pm 5.0 \times 10^{0} \mathrm{bA}$ & $6.1 \times 10^{2} \pm 1.7 \times 10^{2}$ aA & $1.5 \times 10^{3} \pm 1.0 \times 10^{1 \mathrm{bA}}$ & $1.3 \times 10^{3} \pm 2.5 \times 10^{2} \mathrm{bB}$ \\
\hline 14 & $3.6 \times 10^{4} \pm 3.3 \times 10^{2} \mathrm{CB}$ & $1.8 \times 10^{4} \pm 4.4 \times 10^{3} \mathrm{bcB}$ & $1.7 \times 10^{4} \pm 5.6 \times 10^{2}$ bВ & $7.3 \times 10^{2} \pm 1.2 \times 10^{2} \mathrm{aA}$ \\
\hline \multicolumn{5}{|c|}{ Lactic acid bacteria count (CFU/g) } \\
\hline 0 & $1.5 \times 10^{1} \pm 5.0 \times 10^{0 \mathrm{bA}}$ & $1.0 \times 10^{0} \pm 0.0^{\mathrm{aA}}$ & $1.0 \times 10^{1} \pm 0.0^{\mathrm{bA}}$ & $1.0 \times 10^{0} \pm 0.0^{\mathrm{aA}}$ \\
\hline 7 & $5.2 \times 10^{2} \pm 1.2 \times 10^{2}$ bB & $5.6 \times 10^{1} \pm 1.5 \times 10^{1} \mathrm{aA}$ & $2.0 \times 10^{2} \pm 8.8 \times 10^{0} \mathrm{bA}$ & $2.6 \times 10^{0} \pm 1.2 \times 10^{0 \mathrm{bA}}$ \\
\hline 14 & $4.4 \times 10^{3} \pm 2.5 \times 10^{2} \mathrm{aB}$ & $2.6 \times 10^{3} \pm 4.4 \times 10^{2} \mathrm{aB}$ & $1.8 \times 10^{4} \pm 1.6 \times 10^{3} \mathrm{bB}$ & $1.9 \times 10^{3} \pm 8.2 \times 10^{2} \mathrm{aB}$ \\
\hline \multicolumn{5}{|c|}{ Brohothrix thermosphacta count (CFU/g) } \\
\hline 0 & $2.5 \times 10^{3} \pm 4.7 \times 10^{2}$ ьв & $1.5 \times 10^{3} \pm 1.0 \times 10^{1} \mathrm{aB}$ & $1.8 \times 10^{3} \pm 1.1 \times 10^{2}$ aв & $2.8 \times 10^{3} \pm 3.6 \times 10^{2} \mathrm{bB}$ \\
\hline 7 & $2.3 \times 10^{3} \pm 2.7 \times 10^{2}$ bB & $2.0 \times 10^{3} \pm 2.0 \times 10^{2} \mathrm{abB}$ & $2.2 \times 10^{3} \pm 2.1 \times 10^{2}$ ьв & $1.8 \times 10^{3} \pm 2.0 \times 10^{0} \mathrm{aB}$ \\
\hline 14 & $1.7 \times 10^{3} \pm 7.6 \times 10^{2} \mathrm{cA}$ & $1.2 \times 10^{3} \pm 2.0 \times 10^{2} \mathrm{bA}$ & $8.8 \times 10^{2} \pm 2.6 \times 10^{2} \mathrm{bA}$ & $3.5 \times 10^{2} \pm 1.0 \times 10^{1}$ aA \\
\hline
\end{tabular}

Explanations: $\mathrm{C}$ - product without the addition of sage extract and chitosan formulation (control); $\mathrm{S}$ - product with the addition of $2.0 \%(\mathrm{w} / \mathrm{w})$ aqueous sage extract; $\mathrm{CH}$ - product with the addition of $1.0 \%(w / w)$ chitosan formulation; $\mathrm{SCH}$ - product with the addition of $2.0 \%(w / w)$ aqueous sage extract and $1.0 \%(w / w)$ chitosan formulation; nd - not detected; a, b, c - mean values within the same row with different superscript letters differ significantly at $p<0.05$ among treatments for a given time; ${ }^{\mathrm{A}, \mathrm{B}}$ - mean values within the same column with different superscript letters differ significantly at $p<0.05$ among storage time for a given treatment significantly $(p<0.05)$ in the total count of mesophilic aerobic microorganisms, and the highest growth-impeding efficiency of this group was exhibited by the $\mathrm{SCH}$ product containing both aqueous sage extract and chitosan formulation (Tab. 2).

Regardless of the modification of the recipe composition, the chicken meat burgers were found to contain psychrotrophic bacteria (Tab. 2). Throughout the storage time, the control product (C treatment) showed the highest $(\mathrm{p}<0.05)$ contamination with this bacterial group, with the count ranging between $5.6 \times 10^{2} \mathrm{CFU} / \mathrm{g}$ on day 0 and $5.1 \times 10^{4} \mathrm{CFU} / \mathrm{g}$ on day 14 . On day 7 of storage, the count of psychrotrophic bacteria in S, $\mathrm{CH}$, and $\mathrm{SCH}$ products was significantly $(\mathrm{p}<0.05)$ lower than in $\mathrm{C}$ product. Independent of the product treatment a significant $(p<0.05)$ increase in the count of psychrotrophic bacteria was observed between days 7 and 14 of storage. On day 14 , the lowest $(p<0.05)$ count of psychrotrophic bacteria was observed in $\mathrm{SCH}$ product. The obtained results indicate that the inhibiting effect of the applied bioactive natural components on the growth of mesophilic aerobic microorganisms as well as psychrotrophic contamination was noted in $\mathrm{C}$ product, in which the count of mesophilic aerobic microorganisms was determined as $4.0 \times 10^{1} \mathrm{CFU} / \mathrm{g}$ directly after production (day 0) and increased to $9.6 \times 10^{4} \mathrm{CFU} / \mathrm{g}$ on day 14 . The total count of mesophilic aerobic microorganisms in the control product ( $\mathrm{C}$ treatment) was significantly $(p<0.05)$ higher in comparison with the remaining burger treatments, on day 7 as well as day 14 of storage. The lowest count of mesophilic aerobic microorganisms was determined in the product containing aqueous sage extract (S treatment) on the day of production, which was significantly $(p<0.05)$ lower than in product $\mathrm{C}$. However, no significant $(\mathrm{p}<0.05)$ differences could be found between $\mathrm{S}, \mathrm{CH}$, and $\mathrm{SCH}$ products. A significant $(p<0.05)$ increase in the count of mesophilic aerobic microorganisms was found between 7 and 14 days of storage in all burger treatments. In addition, on day 14, all the burger treatments differed bacteria in burgers was more efficient during the first 7 days of storage.

Throughout the storage time, no presence of coliforms could be determined in chicken meat burgers, independent of the type of natural bioactive compound added (Tab. 2). The absence of these bacteria suggested, among other things, the good hygienic quality of the meat used for production. However, the count of Pseudomonas bacteria was variable in the burgers depending on the modification of the recipe composition (Tab. 2). The lowest count of this bacteria group was detected in S product on day 7 of storage. After 7 days, the differences in the count of Pseudomonas between chicken meat burgers were not significant $(p>0.05)$. On day 14 , the lowest $(p<0.05)$ count of these bacteria was determined in $\mathrm{SCH}$ product.

On the production day (day 0), no increase in the count of LAB could be observed in chicken meat burg- 
ers containing aqueous sage extract $(\mathrm{S})$ and sage extract together with chitosan formulation ( $\mathrm{SCH}$; Tab. 2). The LAB count increased significantly $(p<0.05)$ in $\mathrm{C}$ product between days 0 and 7 of storage, whereas in burgers with bioactive components the count increased between days 7 and 14. After 14 days, SCH, $\mathrm{S}$, and $\mathrm{C}$ products had a significantly $(\mathrm{p}<0.05)$ lower LAB count than $\mathrm{CH}$ product. Analysis of the obtained results showed that among the applied modifications of recipe composition, the weakest inhibiting effect on the growth of LAB observed in chicken meat burgers was caused by the addition of chitosan (CH treatment).

The presence of $B$. thermosphacta bacteria was observed in all chicken meat burger treatments throughout the storage time (Tab. 2). On the production day, the lowest count of these bacteria was found in products $\mathrm{S}$ and $\mathrm{CH}$. The bacterial count decreased in burgers with storage time independent of the applied modifications in their recipe composition, and a significant $(\mathrm{p}<0.05)$ decrease was noted in each product between 7 and 14 days of storage. This indicates that the addition of aqueous sage extract, chitosan formulation, and in particular their combination ( $\mathrm{S}, \mathrm{CH}$, and $\mathrm{SCH}$, respectively) efficiently inhibited the growth of $B$. thermosphacta in chicken meat burgers.

Apart from Pseudomonas bacteria, B. thermosphacta are considered to be a "freshness indicator" of certain meat products. They are not pathogens; however, they may cause spoilage of packed meat and meat products stored under refrigeration temperature (2).

A comparable to our results microbial quality in the vacuum-packed chicken meat burgers was observed in the studies of Pietrzak et al. (23). A mesophilic aerobic bacterial count of $8.4 \times 10^{2} \mathrm{CFU} / \mathrm{g}$ and psychrotrophic bacteria count of $5.5 \times 10^{1} \mathrm{CFU} / \mathrm{g}$ were found in control products after 1 day of storage. No growth of LAB, coliforms bacteria, and Enterococci was detected in the products.

The results of an earlier study that compared the antimicrobial activity of formulations obtained from selected spice plants advocated the application of aqueous sage extract to improve the microbiological quality and shelf life of chicken meat burgers (12). Hać-Szymańczuk et al. (11) determined the minimal inhibitory concentration (MIC) and minimal bactericidal concentration (MBC) of sage, rosemary, and oregano aqueous extracts, as well as the growth inhibition zones of selected bacteria, using the disk/ agar diffusion method. The strongest inhibitory (MIC) and bactericidal (MBC) effect toward the majority of the tested bacteria was exhibited by aqueous sage extract. According to Mizi et al. (17), sage contains the following antimicrobial compounds: phenolic acids (e.g. rosmarinic, syringic acid), monoterpenes (e.g. 1-8-cineole, $\beta$-thujone, $\alpha$-thujone), and diterpenes (e.g. carnosol and carnosic acid).
The results of our study indicate that aqueous sage extract and chitosan formulation inhibited the growth of both Gram-positive and Gram-negative bacteria (Tab. 2). The literature relates the differences in the sensitivity of these bacterial groups with the active substances contained in sage (9). This is due to the variations in the interactions between the antibacterial compounds in sage and the surface of bacterial cells. In Gram-negative bacteria, the diffusion of antimicrobial components into the cells is impeded, because they are encapsulated in an external membrane consisting of peptidoglycan and lipopolysaccharide complex.

The practical application of different sage formulations as natural components for improving the shelflife and safety of poultry meat and its products was assessed by Petrová et al. (21). Significant restriction in the growth of Enterobacteriaceae in vacuum-packed chicken breast stored under refrigeration temperature for 16 days resulting from the addition of $2.0 \%$ essential oil extracted from $S$. officinalis L. in combination with ethylenediamine tetraacetic acid was observed. Karpińska-Tymoszczyk (15) determined that the addition of $0.1 \%$ sage ethanol extract to turkey meatballs reduced the count of mesophilic aerobic microorganisms by one logarithmic cycle. Hać-Szymańczuk et al. (12) demonstrated that the quality of MSM from chickens stored at $4-6^{\circ} \mathrm{C}$ for 14 days can be improved by adding any sage formulation: essential oil or ethanol or aqueous extract. Independent of the type of plant formulation, a significant reduction in the growth of mesophilic aerobic bacteria, psychrotrophic bacteria, Enterobacteriaceae, and Enterococci bacteria was noted. The aqueous sage extract and other formulations were also used successfully for MSM from "Baader" chicken type stored in frozen form (5). It was discovered that the extract exhibited an antimicrobial effect against Enterobacteriaceae, coliforms, and Enterococci similar to the action of essential oil.

Due to antimicrobial activity chitosan and its derivatives have become the subjects of research not only in the fields of medicine and agriculture but also in food production (7). A study showed that the application of chitosan coating in ready-to-cook meat products, such as chicken balls and chicken kebabs, eliminated fecal coliform bacteria and reduced the total count of viable bacteria and the count of Staphylococcus spp. (14).

The obtained results show that due to their bioactive properties, aqueous sage extract and chitosan formulation can be applied in order to extend the shelf-life and safety of convenience foods from chicken meat.

Addition of aqueous sage extract was the most efficient in reducing the oxidative changes of lipids in vacuum-packed chicken meat burgers during refrigeration storage for 14 days. Both aqueous sage extract and chitosan formulation exhibited antibacterial activities in chicken meat burgers, although the efficiency of growth inhibition differed between the 
tested bacterial groups. During the 14-day storage of burgers, the growth of $B$. thermosphacta was most effectively inhibited by the combined addition of sage extract and chitosan formulation. Because a significant increase was noted in the counts of the majority of the determined bacterial groups between 7 and 14 days, the storage time of burgers can be shortened. Alternatively, the amount of sage extract and chitosan formulation can be increased to enhance the microbiological quality of such products, under the condition of obtaining sensory approval for the product. Sensory quality assessment of chicken burgers with sage aqueous extract and chitosan formulation is necessary in order to obtain full product quality characteristics.

\section{References}

1. Amaral A. B., Silva M. V. da, Silva Lannes S. C. da: Lipid oxidation in meat: mechanisms and protective factors - a review. Food Sci. Tech.-Brasil. 2018, 38, 1-15, doi: 10.1590/fst.32518.

2. Ambrosiadis J., Soultos N., Ambrahim A., Bloukas J. G.: Physicochemical, microbiological and sensory attributes for the characterization of Greek traditional sausages. Meat Sci. 2004, 66, 279-287, doi: 10.1016/s0309-1740(03)00100-1.

3. Bagnowska A., Krala L., Nowak A., Oracz J.: Właściwości przeciwutleniające chitozanu w kiełbasach bez dodatku azotanu (III). Żywność. Nauka. Technologia. Jakość 2014, 95, 173-187, doi: 10.15193/ZNTJ/2014/95/173-187.

4. Cegiełka A., Hać-Szymańczuk E.: Chitozan, naturalny biopolimer przedłużający trwałość produktów. Przem. Spoż. 2018, 72, 34-37, doi: 10.15199/65.2018.5.4.

5. Cegiełka A., Hać-Szymańczuk E., Piwowarek K., Dasiewicz K., Słowiński M., Wrońska $K$.: The use of bioactive properties of sage preparations to improve the storage stability of low-pressure mechanically separated meat from chickens. Poultry Sci. 2019, 98, 5045-5053, doi: 10.3382/ps/pez242.

6. Gantner M., Brodowska M., Górska-Horczyczak E., Wojtasik-Kalinowska I., Najda A., Pogorzelska E., Godziszewska J.: Antioxidant effect of sage (Salvia officinalis L.) extract on turkey meatballs packed in cold modified atmosphere. CYTA - J. Food 2018, 16, 628-636, doi: 10.1080/19476337.2018.1426632.

7. Georgantelis D., Ambrosiadis I., Katikou P., Blekas G., Georgakis S. A.: Effect of rosemary extract, chitosan and a-tocopherol on microbiological parameters and lipid oxidation of fresh pork sausages stored at $4^{\circ} \mathrm{C}$. Meat Sci. 2007, 76, 172-181, doi: 10.1016/j.meatsci.2006.10.026.

8. Georgantelis D., Blekas G., Katikou P., Ambrosiadis I., Fletouris D. J.: Effect of rosemary extract, chitosan and $\alpha$-tocopherol on lipid oxidation and colour stability during frozen storage of beef burgers. Meat Sci. 2007, 75, 256-264, doi: 10.1016/j.meatsci.2006.07.018.

9. Gómez-Estaca J., López Lacey A. de, López-Caballero M. E., Gómez-Guillen M. C., Montero P.: Biodegradable gelatin-chitosan films incorporated with essential oils as microbial agents for fish preservation. Food Microbiol. 2010, 27, 889-896, doi: 10.1016/j.fm.2010.05.012.

10.Hać-Szymańczuk E., Cegiełka A.: Ocena aktywności przeciwdrobnoustrojowej i przeciwutleniającej szałwii lekarskiej w produkcie mięsnym. Żywność. Nauka. Technologia. Jakość 2015, 100, 84-94, doi: 10.15193/ zntj/2015/100/042.

11.Hać-Szymańczuk E., Cegiełka A., Lipińska E., Czapska S.: Analiza składu chemicznego i aktywności przeciwdrobnoustrojowej ekstraktów wodnych z wybranych roślin przyprawowych. Zesz. Probl. Post. Nauk Rol. 2015, 582, 3-11.

12.Hać-Szymańczuk E., Cegiełka A., Lipińska E., Ilczuk P.: Wpływ szałwii na jakość mikrobiologiczną oraz wartość wskaźnika TBA w mięsie drobiowym odzyskanym mechanicznie. Med. Weter. 2014, 70, 704-708.

13. Hać-Szymańczuk E., Lipińska E., Chlebowska-Śmigel A.: Porównanie działania przeciwdrobnoustrojowego olejków eterycznych z szałwii (Salvia officinalis L.) i oregano (Origanum vulgare L.). Zesz. Probl. Post. Nauk Rol. 2014, 577, 53-63.

14. Kanatt S. R., Rao M. S., Chawla S. P., Sharma A.: Effects of chitosan coating on shelf-life of ready-to-cook meat products during chilled storage. LWT Food Sci. Technol. 2013, 53, 321-326, doi: 10.1016/j.lwt.2013.01.019.

15. Karpińska-Tymoszczyk M.: Effects of sage extract (Salvia officinalis L.) and a mixture of sage extract and sodium isoascorbate on the quality and shelf life of vacuum-packed turkey meatballs. J. Muscle Foods 2007, 18, 420-434, doi: 10.1111/j.1745-4573.2007.00096.x.

16. Karre L., Lopez K., Getty K. J. K.: Natural antioxidants in meat and poultry products. Meat Sci. 2013, 94, 220-227, doi: 10.1016/j.meatsci.2013.01.007.

17. Mizi L., Cofrades S., Bou R., Pintado T., López-Caballero M., Zaidi F., JiménezColmenero F: Antimicrobial and antioxidant effects of combined high pressure processing and sage in beef burgers during prolonged chilled storage. Innov. Food Sci. Emerg. Technol. 2019, 51, 32-40, doi: 10.1016/j.ifset.2018.04.010.

18. Montaño-Sánchez E., Mar Torres-Martínez B. del, Vargas-Sánchez R. D., Huerta-Leidenz N., Sánchez-Escalante A., Beriain M. J., Torrescano-Urrutia $G$. R.: Effects of chitosan coating with green tea aqueous extract on lipid oxidation and microbial growth in pork chops during chilled storage. Foods 2021, 9, 1-12, doi: 10.3390/foods9060766

19. Nowak A., Rygała A., Ottuszak-Walczak E., Walczak P.: The prevalence and some metabolic traits of Brochothrix thermosphacta in meat and meat products packaged in different ways. J. Sci. Food Agric. 2012, 92, 1304-1310, doi: $10.1002 /$ jsfa.4701.

20. Ozaki M. M., Munekata P. E. S., de Souza Lopes A., da Silva do Nascimento M., Pateiro M., Lorenzo J. M., Rodrigues Pollonio A. M.: Using chitosan and radish powder to improve stability of fermented cooked sausages. Meat Sci. 2020, 167, 108165:1-108165:13, doi: 10.1016/j.meatsci.2020.108165.

21. Petrová J., Pavelková A., Hleba L., Pochop J., Rovná K., Kačaniová M.: Antimicrobial effect of Salvia officinalis L. against selected group of bacteria isolated from chickens meat. Sci. Pap. J. Anim. Sci. Biotechnol. 2013, 46, 123-127.

22. Pietrzak D.: Perspektywy stosowania wysokich ciśnień w produkcji żywności wygodnej z mięsa drobiowego. Żywność. Nauka. Technologia. Jakość 2010, 69, 16-28.

23. Pietrzak D., Trejda E., Ziarno M.: Wpływ wysokiego ciśnienia na wybrane właściwości oraz trwałość kotlecików z mięsa drobiowego. Żywność. Nauka. Technologia. Jakość 2011, 74, 68-78.

24. Pikul J., Leszczyński D. E., Kummerow F. A.: Evaluation of three modified TBA methods for measuring lipid oxidation in chicken meat. J. Agr. Food Chem. 1989, 37, 1309-1313.

25. PN-A-82109:2010. Mięso i przetwory mięsne. Oznaczanie zawartości tłuszczu, białka i wody. Metoda spektrometrii transmisyjnej w bliskiej podczerwieni (NIT) z wykorzystaniem kalibracji na sztucznych sieciach neuronowych (ANN).

26. PN-EN ISO 4833-1:2013-12. Mikrobiologia łańcucha żywnościowego. Horyzontalna metoda oznaczania liczby drobnoustrojów. Część 1: Oznaczanie liczby metodą posiewu wgłębnego w temperaturze 30 stopni $\mathrm{C}$.

27. PN-EN ISO 6887-2:2005. Mikrobiologia żywności i pasz. Przygotowanie próbek, zawiesiny wyjściowej i rozcieńczeń dziesięciokrotnych do badań mikrobiologicznych. Część 2: Specyficzne zasady przygotowania mięsa i przetworów mięsnych.

28. PN-ISO 4832:2007. Mikrobiologia żywności i pasz. Horyzontalna metoda oznaczania liczby bakterii z grupy coli. Metoda płytkowa.

29. PN-EN ISO 13720:2010. Mięso i przetwory mięsne. Oznaczanie liczby przypuszczalnych Pseudomonas sp.

30. PN-ISO 15214:2002. Mikrobiologia żywności i pasz. Horyzontalna metoda oznaczania liczby mezofilnych bakterii fermentacji mlekowej. Metoda płytkowa w temperaturze 30 stopni C.

31. PN-ISO 17410:2004. Mikrobiologia żywności i pasz. Horyzontalna metoda oznaczania liczby drobnoustrojów psychrotrofowych.

32. Raafat D., Sahl H.-G.: Chitosan and its antimicrobial potential - a critical literature survey. Microb. Biotechnol. 2009, 2, 186-201, doi: 10.1111/j.17517915.2008.00080.x.

33. Sayas-Barberá E., Quesada J., Sánchez-Zapata E., Viuda-Martos M., Fernández-López F., Pérez-Alvarez J. A., Sendra E.: Effect of the molecular weight and concentration of chitosan in pork model burgers. Meat Sci. 2011, 88, 740-749, doi: 10.1016/j.meatsci.2011.03.007.

34. Sohaib M., Anjum F. M., Arshad S. M., Imran M., Imran A., Hussain S.: Oxidative stability and lipid oxidation flavoring volatiles in antioxidants treated chicken meat patties during storage. Lipids Health Dis. 2017, 16, 1-27, doi: 10.1186/s12944-017-0426-5.

35. Vargas M., Albors A., Chiralt A.: Application of chitosan-sunflower oil edible films to pork meat hamburgers. Proc. Food Sci. 2011, 1, 39-43, doi: 10.1016/ j.profoo.2011.09.007.

Corresponding author: Aneta Cegiełka, PhD, Department of Food Technology and Food Evaluation, Institute of Food Sciences, Warsaw University of Life Sciences - SGGW, Nowoursynowska 166, 02-787 Warsaw, Poland; e-mail: aneta_cegielka@sggw.edu.pl 